\title{
Tackling Transition: The Value of Peer Mentoring ${ }^{1}$
}

\author{
Robin Clark \\ Aston University \\ Email: r.p.clark@aston.ac.uk \\ Jane Andrews \\ Aston University \\ Email: j.e.andrews@aston.ac.uk \\ Paul Gorman \\ Aston University \\ Email: p.gorman@aston.ac.uk
}

\begin{abstract}
This paper is aimed at those interested in the promotion of student retention in higher education; particularly those with an interest in peer mentoring as a means of student support. It critically discusses the results of an exploratory study analysing the perceptions of peer mentors and mentees within five universities in the United Kingdom. The aim of the study was to analyse how student peer mentoring can aid transition into university by focusing specifically on how senior students can support their junior counterparts in their first year at university. The paper discusses the results of a survey which was completed by 329 student peer mentors and mentees. Focusing on the benefits and outcomes of participation in Mentoring Programmes, the survey was distinctive in that it asked mentors and mentees similar questions. From a theoretical perspective, the paper contributes to debates about peer support in higher education showing that participation in such programmes can have positive outcomes from both social and pedagogic perspectives. Practically speaking, the results have important implications for Higher Education Institutions as the research highlights the importance of putting into place formally structured Peer Mentoring Programmes which facilitate student support at a time when new students are most at risk of 'dropping out'.
\end{abstract}

Key terms: peer mentoring; peer support; transition; retention; success; belonging.

\footnotetext{
${ }^{1}$ This study is part of a larger investigation into the value of peer mentoring in Higher Education, the results and outputs from which may be found at: http://www1.aston.ac.uk/eas/research/groups/eerg/
} 


\section{Introduction}

Over the past two decades, massification of the UK Higher Education Sector has brought with it increased class sizes and a more diverse student population (Kreber, 2006). Such expansion has been met with concerns regarding what is often perceived to be an increasingly wide 'gap' between the skills and capabilities of graduates, and the requirements and demands of the work environment (Teichler, 2003). It is within this setting that the need to promote the early first year student experience (Watson et al, 2004) has become increasingly important as universities seek to market themselves to potential students. Whilst the impact of the current policy and funding environment, in which students are expected to pay an average of $£ 8,600$ per year tuition fees (Paton, 2011), is yet to be fully realised, there can be little argument that 'Freshers' arriving at their new universities in the autumn of 2012 will each bring with them a set of high expectations. Reflective of the fact that the responsibility for funding higher education has changed from state to consumer, such expectations are likely to be both academic and socio-psychological in nature. Put simply, students are paying more for their university education and are therefore likely to expect more of, and from, their universities.

Peer mentoring represents an increasingly popular form of student support, found within around 50\% of UK Higher Education Institutions (Andrews et al, 2009). It involves senior students, usually in the second, third or final year of their Bachelor's Degrees, offering pastoral (social and welfare focused) and / or academic support on a formally organised, voluntary (unpaid) basis to their junior counterparts (for further discussion see Axon, 2012; Clark and Andrews, 2012). One form of peer mentoringtransitional peer mentoring-aims to provide student support at a crucial time in an individual's learning journey-during their first few weeks of university. It is this type of peer mentoring that was the focus of this study.

Drawing upon a large research project critiquing the social, pedagogical and organisational value of transitional peer mentoring programmes in five UK universities, this paper provides an analysis of the benefits and challenges of peer mentoring in higher education. Across the five universities included in the study, 12 different peer mentoring programmes were analysed using a survey methodology. Drawing on research undertaken within a complex and continually changing environment, this paper critically discusses students' perceptions of the value of peer mentoring. In doing so it highlights the value of peer mentoring both as a volunteering activity for peer mentors and also as a support mechanism for peer mentees. 


\section{Background}

\section{What is Mentoring and Peer Mentoring?}

Across the literature there exists a notable body of work analysing and critiquing the concept of mentoring within an organisational or workfocused setting (see for example Jacobi, 1991 and D'Abate et al, 2003). Traditionally, mentoring relationships are conceived to be dyadic in nature (Kram, 1983; Chandler and Kram, 2005), and with the mentor having more knowhow, expertise or prestige than the mentee (Blackwell, 1989; Peyton et al, 2001). Within an organisational hierarchy, mentors are generally senior to, and more experienced than, mentees (Moore and Amey, 1988). They are usually viewed as positive role models who use their expertise, experience and position to promote, encourage, sponsor and guide the career and personal development of their mentees (Kram, 1983; Topping \& Ehly, 2001; Enhrich et al, 2004).

Whilst issues around traditional mentoring within an organisational setting have been well documented and researched, peer mentoring in higher education lacks critique and is less clearly defined. This lack of clarity is reflected in the multiplicity of terms used to conceptualise peer mentoring with a variety of terminologies in use to conceptualise and 'capture' informal and formal mentoring and other associated activities between students. Phrases such as peer-assisted learning, peer tutoring and peer mentoring are often used interchangeably resulting in some confusion regarding the meaning and context of each term (Reid et al; 1997; Topping, 1996, 2005). In arguing that such confusion may reflect linguistic anomalies between different English speaking countries, Topping and Ehly (2001) drew together the different perspectives under the heading 'peer mentoring' and suggested that in contradiction to perceptions of traditional mentoring as being hierarchical in nature, peer mentoring is based upon mutuality. Moreover, manifested by a relationship between people of equal status, peer mentoring has a significant element of reciprocity in which mentor and mentee both contribute and exchange knowledge and share interests (Topping \& Ehly, 2001).

\section{Is Peer Mentoring Student Volunteering?}

Whilst on the surface it appears that peer mentoring in higher education represents a distinctive type of voluntary activity in that it encapsulates student and institutional needs, the benefits of participation for student mentors in particular should not be underestimated. Previous studies into student volunteering suggest that formally organized activities such as peer mentoring have social, economic and practical benefits for both the student volunteers and the recipients of their volunteerism (Egerton, 2002; Vernon \& Foster, 2002). From a wider policy perspective, other literature suggests 
that volunteering amongst young people has increasingly been seen as a 'quick fix' for a wide variety of youth related issues and problems ranging in focus from skills development to the rehabilitation of young offenders (Hill et al, 2009).

Whilst it may be argued that it is inappropriate to conceptualise university student volunteering activities such as peer mentoring as a 'quick fix' for societal problems, there can be little doubt that it can potentially provide a solution for current organisational issues around student support. Indeed, the potential for student volunteering as an 'institutional good' was highlighted in the National Framework for Youth Engagement and Action (Russell, 2005), a policy document that specifically aimed to deliver positive change in the quality and range of volunteering opportunities available to young people. Since this time there have been several national initiatives targeted at young people, perhaps the most high profile of which is $\mathbf{v}$, an independent charity launched in May 2006 with the remit of helping young people volunteer in ways that matter to them (vinspired, 2010).

Whilst outside the university sphere, the success of such initiatives is contested (DCLG, 2009), when considering the volunteering activities of students in higher education, positive correlations with education, employment and income (Attwood et al., 2003; Davis Smith et al., 2002) suggest that the very act of being in education is a significant factor influencing the experiences and outcomes of student volunteering. It is within this context that peer mentoring in higher education is conceptualised as 'volunteering'. 


\section{The Benefits \& Challenges of Peer Mentoring in Higher Education}

Prior to considering the benefits and challenges associated with peer mentoring, and in order to add context, the issues around traditional mentoring are first discussed. With regards to mentees' perspectives, the literature identifies various benefits of traditional mentoring. Such benefits range from the opportunity to develop a meaningful relationship with a senior colleague (Levinson et al 1978; Levinson and Levinson, 1996) to increased motivation (Enhrich et al, 2004). Participation in traditional mentoring also affords the opportunity for individuals to access support and counselling within the workplace (Jacobi, 1991; Enhrich et al, 2004; Eby et al, 2008). Similarly, through being paired with a more senior student, participation in transitional peer mentoring provides new students with someone who can fully empathise with their situation. It provides the opportunity for Freshers to quickly build relationships with peers who fully understand the potential difficulties and pressures associated with making the move from school or college to university (Cropper, 2000).

Whilst the benefits of peer mentoring for student mentees have been previously discussed, the benefits for student peer mentors are less clearly established. The wider mentoring literature provides insight into benefits for mentors of participating in traditional mentoring activities within a workfocused setting. Such benefits range from increased self-esteem and selfconfidence, to greater organisational status and collegiality, and increased levels of job satisfaction (Kram, 1985; Ragins \& Scandura, 1994; Enhrich et al, 2004). It is important to note that whilst it is possible that, like those engaged in traditional mentoring, volunteer student mentors also gain individual psycho-social and career-related value from participating in university based mentoring programmes, prior to this study this had not been empirically proven. However, one positive outcome of participation in mentoring for volunteer student mentors that has been widely researched is the opportunity to 'learn through teaching' (Hartman; 1990; Anderson and Boud, 1996; Topping, 2005).

From the HEI perspective, improved academic achievement and increased levels of student retention mean that peer mentoring can represent a valuable method of addressing issues around attrition and failure (Congos and Schoeps, 1993; Cropper, 2000; Fox \& Stevenson, 2006). Another institutional benefit afforded by peer mentoring programmes relates to enhanced levels of student satisfaction regarding the overall quality of the university experience. This engenders a sense of belonging and institutional identity manifested as an increased commitment to the institution (Sanchez et al. 2006). 
In bringing together the literature pertaining to student volunteering, traditional mentoring and student peer mentoring, it is possible to identify three thematic areas relevant to the value of formally organised voluntary mentoring programmes within higher education: individual benefits, social outcomes, and organizational factors. Each of these themes was taken account of in the development of the methodological approach to the research as outlined below.

\section{The Peer Mentoring Study: Methodology}

Commencing with the hypothesis that transitional peer mentoring impacts positively on students' experiences by engendering a greater sense of belonging both socially and academically, the primary aim of the study was to clearly identify and critically analyse the key determinants of peer mentoring in facilitating a successful transition into higher education for new students. Additionally, in seeking to provide useful information for Higher Education Institutions (HEIs) wishing to establish peer mentoring programmes and recruit peer mentors, the study also sought to identify and analyse the value of peer mentoring from student mentors' perspectives. To achieve these aims, students engaged in peer mentoring programmes at five different UK universities were surveyed. The HEIs comprised two newer (post-1992 universities), two 1960s research intensive universities and a Russell Group university. The perceptions of students' participating in fourteen different peer mentoring programmes were captured by the survey. For the purposes of the study the programmes were classified into six different categories:

\section{Short-term Transitional Peer Mentoring}

Three institutions offer peer mentoring programmes that focus upon the first few weeks of a new student's first term at University. This form of peer mentoring is pastoral in nature and involves second and final year students mentoring 'Freshers' to help them deal with the numerous academic and social challenges associated with moving to a new environment.

\section{Subject-Specific Transitional Peer Mentoring}

Offered at three institutions, this category of peer mentoring involves one second year peer mentor being allocated to a group of between three and five students from their own discipline area. The purpose of these programmes is to allow new students to form relationships with more senior students in their own School or Faculty. Such relationships tend to the first few weeks at university, but extend for some through the whole of the academic year and beyond. 


\section{Compulsory 'Formal' Transitional Peer Mentoring}

At one institution all first year students are allocated a peer mentor to work with them throughout the first term. Each peer mentor helps new students settle in and deal with any personal, academic or social issues which may arise. Within this model there are generally four or five mentees to each mentor - with the relationship often lasting into the second term and beyond.

\section{Targeted 'Formal' Transitional Peer Mentoring}

Three institutions offer this type of peer mentoring which involves the targeting of 'non-traditional' students who are then paired with a mentor from a similar demographic / socio-economic background. The peer mentor works with the mentee on a one-to-one basis during the first few weeks of term, helping them overcome any issues and building a relationship which generally continues throughout the first year and beyond.

\section{Voluntary Opt-in 'Formal' Transitional Peer Mentoring}

Offered by one of the institutions, this large optional mentoring programme involves second and final year peer mentors working with first years on a one-to-one basis. The programme is widely advertised across the institution and covers all aspects of the academic experience.

\section{Pre-University e-Mentoring}

Currently being offered at three of the institutions, peer mentors contact future students following the release of ' $A$ ' level results and form a 'virtual' relationship. This relationship then continues on a face-to-face basis once the term starts. In all three institutions peer mentors are 'matched' with peer mentees depending on both focus of degree and demographic characteristics.

Working in collaboration with partners from each of the five universities, a survey tool was developed aimed at capturing the value of peer mentoring from the perspectives of all of the students' involved. Following a period of consultation amongst the partners it was decided not to differentiate between the different types of mentoring programmes offered by the institutions but instead concentrate on the commonalities across each of the programmes. The survey covered both academic and social issues and encapsulated four distinctive areas of university life:

- thoughts and anxieties before starting university;

- the social impact of participation in peer mentoring;

- the academic impacts of participation in peer mentoring; and

- the relational aspects of peer mentoring. 
After much discussion, it was decided to ask peer mentors and mentees the same questions; hence both groups were surveyed simultaneously utilising the same research instrument. The reasoning behind this decision was to allow the researchers the opportunity to draw a comparison of the value of mentoring from the perspective of the two groups. The survey was administered across all six institutions concurrently, resulting in a total of 329 completed questionnaires - a response rate of just under $10 \%$.

Following administration of the survey, the data was coded and exported to a statistical software package for analysis. All results were generated using the software and the percentages were rounded to one decimal point.

\section{Findings}

The analysis revealed that $44 \%$ of the respondents were peer mentors and $56 \%$ were mentees. Around $75 \%$ were female and the majority were aged 18 to 20 years. The vast majority were full-time, UK / EU students, with over $50 \%$ indicating that they lived off campus in rented accommodation. Over $75 \%$ identified their ethnicity as white, with a wide range of other ethnic backgrounds represented by the other respondents. Just under 5\% stated that they have a disability.

The first area covered by the survey captured students' perceptions of their anxieties before starting university. Table 1 shows the differences between the two groups. 
Table 1: Before Starting University: Student Mentees (M1) and Mentors (M2)

\begin{tabular}{|c|c|c|c|c|c|c|c|c|c|c|}
\hline \multirow[t]{2}{*}{$\begin{array}{l}\text { Before } \\
\text { Starting } \\
\text { University.... }\end{array}$} & \multicolumn{2}{|c|}{$\begin{array}{l}\text { Strongly } \\
\text { agree \% }\end{array}$} & \multicolumn{2}{|c|}{ Agree \% } & \multicolumn{2}{|c|}{ Neutral \% } & \multicolumn{2}{|c|}{ Disagree \% } & \multicolumn{2}{|c|}{$\begin{array}{l}\text { Strongly } \\
\text { disagree } \\
\%\end{array}$} \\
\hline & M1 & M2 & M1 & M2 & M1 & M2 & M1 & M2 & M1 & M2 \\
\hline $\begin{array}{l}\text {...I was } \\
\text { anxious } \\
\text { about making } \\
\text { new friends }\end{array}$ & 26.5 & 22.0 & 44.0 & 49.2 & 13.3 & 9.1 & 12.7 & 15.9 & 3.6 & 3.8 \\
\hline $\begin{array}{l}\text {...I felt } \\
\text { prepared for } \\
\text { university } \\
\text { level study }\end{array}$ & 10.3 & 12.1 & 37.6 & 49.2 & 23.6 & 18.9 & 23.6 & 19.7 & 4.8 & .0 \\
\hline $\begin{array}{l}\text {...I was } \\
\text { anxious } \\
\text { about } \\
\text { adjusting to } \\
\text { university life }\end{array}$ & 21.2 & 12.9 & 42.4 & 45.5 & 21.8 & 16.7 & 12.1 & 23.5 & 2.4 & 1.5 \\
\hline $\begin{array}{l}\text {...I felt } \\
\text { confident } \\
\text { about } \\
\text { starting } \\
\text { university }\end{array}$ & 8.5 & 11.4 & 37.2 & 43.2 & 23.2 & 18.2 & 27.4 & 25.8 & 3.7 & 1.5 \\
\hline $\begin{array}{l}\text {...I was } \\
\text { confident I } \\
\text { had the } \\
\text { ability to } \\
\text { develop my } \\
\text { subject } \\
\text { knowledge }\end{array}$ & 13.9 & 19.7 & 58.4 & 58.3 & 58.4 & 14.4 & 15.1 & 6.8 & $\begin{array}{l}12 . \\
7\end{array}$ & .8 \\
\hline $\begin{array}{l}\text {...I was } \\
\text { confident I } \\
\text { would be } \\
\text { supported at } \\
\text { university }\end{array}$ & 11.7 & 11.4 & 44.8 & 45.5 & 34.4 & 34.1 & 7.4 & 9.1 & 1.8 & .0 \\
\hline $\begin{array}{l}\text {...I was } \\
\text { confident } \\
\text { about my } \\
\text { communicati } \\
\text { on skills }\end{array}$ & 12.1 & 17.4 & 46.7 & 46.2 & 16.4 & 15.2 & 21.8 & 18.2 & 3.0 & 3.0 \\
\hline $\begin{array}{l}\text {...I was } \\
\text { committed to } \\
\text { completing } \\
\text { my studies at } \\
\text { university }\end{array}$ & 51.5 & 58.3 & 40.7 & 40.9 & 5.4 & .8 & 1.8 & .0 & 6 & .0 \\
\hline
\end{tabular}


The above table suggests whilst the majority of the respondents were anxious about adjusting to university life and making friends, most were confident about their communication skills and were committed to completing their studies, feeling sure that they had the ability to develop their subject knowledge. The data shows that, in looking back, the peer mentors perceived that they were slightly more prepared and confident for university life than the mentees; although this may be reflective of the fact that the mentors were in their second or final year of study and that their perceptions of how they felt before starting university may have changed over time.

Perhaps not surprisingly, although the majority of respondents indicated they felt confident that they would be supported once at university, just over a third responded 'neutrally' to this question - possibly an indication that many were unaware of the available support at their future universities.

The second area of the questionnaire focused on the social impact of participation in mentoring. Table 2 provides an overview of the findings in this area. 
Table 2: The 'Social’ Impact of Student Peer Mentoring

\begin{tabular}{|c|c|c|c|c|c|c|c|c|c|c|}
\hline \multirow{2}{*}{$\begin{array}{l}\text { As a result of } \\
\text { participating in } \\
\text { the Peer } \\
\text { Mentoring } \\
\text { Programme... }\end{array}$} & \multicolumn{2}{|c|}{$\begin{array}{l}\text { Strongly } \\
\text { agree \% }\end{array}$} & \multicolumn{2}{|c|}{ Agree \% } & \multicolumn{2}{|c|}{ Neutral \% } & \multicolumn{2}{|c|}{$\begin{array}{l}\text { Disagree } \\
\%\end{array}$} & \multicolumn{2}{|c|}{$\begin{array}{l}\text { Strongly } \\
\text { disagree } \\
\%\end{array}$} \\
\hline & M1 & M2 & M1 & M2 & M1 & M2 & M1 & M2 & M1 & M2 \\
\hline $\begin{array}{l}\text {...I feel part of the } \\
\text { university }\end{array}$ & 16.3 & 34.8 & 48.8 & 48.5 & 23.5 & 12.9 & 8.4 & 3.8 & 3.0 & .0 \\
\hline $\begin{array}{l}\text {... f feel I am } \\
\text { making more use } \\
\text { of the } \\
\text { opportunities } \\
\text { available at } \\
\text { university }\end{array}$ & 12.7 & 33.3 & 52.1 & 51.5 & 21.8 & 11.4 & 9.7 & 3.0 & 3.6 & .8 \\
\hline $\begin{array}{l}\ldots . \text { am finding my } \\
\text { time at university } \\
\text { more enjoyable }\end{array}$ & 18.1 & 24.2 & 36.7 & 30.3 & 30.1 & 40.2 & 10.8 & 4.5 & 4.2 & .8 \\
\hline $\begin{array}{l}\text {...my confidence } \\
\text { in using student } \\
\text { services has } \\
\text { increased }\end{array}$ & 9.6 & 19.1 & 53.6 & 52.7 & 31.3 & 28.2 & 3.0 & .0 & 2.4 & .0 \\
\hline
\end{tabular}

Table 2 indicates that peer mentoring provides a useful means by which students are able to make the most of their university experiences. That all the statements elicited a positive rather than negative response indicates that participation in peer mentoring promotes a sense of belonging. Another interesting feature of the findings relates to the large number of neutral responses pertaining to enjoying time at university; that the respondents do not particularly associate peer mentoring with enjoyment may well be reflective of the fact that both mentors and mentees alike view peer mentoring in a pragmatic rather than an emotive way.

The third area covered by the questionnaire aimed to capture perceptions of the linkages between peer mentoring and learning. Table 3 gives some indication of the wider educational value of peer mentoring. Of importance is the fact that the programmes included within the survey were generally 'pastoral' in nature - and did not involve tutoring activities (the high number of neutral responses would seem indicative of this). Despite the non-academic focus of the peer mentoring covered by this study, it would seem that for peer mentors in particular, participation in mentoring is perceived to be a positive learning experience. Moreover, the finding that peer mentoring has a favourable impact on mentees commitment and confidence gives some indication of its usefulness in promoting a positive transition into university. 
Table 3: Student Peer Mentoring and Learning: Mentees' [M1] and Mentors' [M2] Perceptions

\begin{tabular}{|c|c|c|c|c|c|c|c|c|c|c|}
\hline \multirow[t]{2}{*}{$\begin{array}{l}\text { Learning and } \\
\text { peer mentoring }\end{array}$} & \multicolumn{2}{|c|}{$\begin{array}{l}\text { Strongly } \\
\text { agree \% }\end{array}$} & \multicolumn{2}{|c|}{ Agree \% } & \multicolumn{2}{|c|}{ Neutral \% } & \multicolumn{2}{|c|}{$\begin{array}{l}\text { Disagree } \\
\%\end{array}$} & \multicolumn{2}{|c|}{$\begin{array}{l}\text { Strongly } \\
\text { disagree } \\
\%\end{array}$} \\
\hline & M1 & M2 & M1 & M2 & M1 & M2 & M1 & M2 & M1 & M2 \\
\hline $\begin{array}{l}\text { Peer mentoring } \\
\text { has positively } \\
\text { influenced the } \\
\text { way I approach } \\
\text { learning }\end{array}$ & 6.1 & 14.7 & 33.9 & 32.6 & 41.2 & 42.6 & 12.1 & 10.1 & 6.7 & .0 \\
\hline $\begin{array}{l}\text { Involvement } \\
\text { with peer } \\
\text { mentoring has } \\
\text { been a positive } \\
\text { learning } \\
\text { experience }\end{array}$ & 12.1 & 23.3 & 43.6 & 61.2 & 29.7 & 14.0 & 7.3 & 1.6 & 7.3 & .0 \\
\hline $\begin{array}{l}\text { Peer mentoring } \\
\text { has increased } \\
\text { my interest in } \\
\text { my subject area }\end{array}$ & 3.6 & 12.5 & 27.3 & 25.8 & 46.7 & 43.0 & 16.4 & 17.2 & 6.1 & 1.6 \\
\hline $\begin{array}{l}\text { Peer mentoring } \\
\text { has helped me } \\
\text { learn } \\
\text { independently }\end{array}$ & 6.7 & 14.1 & 27.9 & 25.8 & 43.6 & 39.1 & 16.4 & 19.5 & 5.5 & 1.6 \\
\hline $\begin{array}{l}\text { As a result of } \\
\text { peer mentoring } \\
\text { my confidence } \\
\text { in succeeding in } \\
\text { my studies has } \\
\text { increased }\end{array}$ & 12.1 & 12.2 & 37.6 & 29.0 & 45.5 & 58.0 & 3.0 & .8 & 1.8 & .0 \\
\hline $\begin{array}{l}\text { As a result of } \\
\text { peer mentoring } \\
\text { my confidence } \\
\text { about my } \\
\text { academic skills } \\
\text { has increased }\end{array}$ & 9.0 & 15.3 & 38.3 & 29.8 & 46.7 & 53.4 & 3.6 & 1.5 & 2.4 & .0 \\
\hline $\begin{array}{l}\text { As a result of } \\
\text { peer mentoring } \\
\text { my subject } \\
\text { knowledge has } \\
\text { increased }\end{array}$ & 10.4 & 9.9 & 38.4 & 29.0 & 49.4 & 60.3 & .0 & .8 & 1.8 & .0 \\
\hline $\begin{array}{l}\text { As a result of } \\
\text { peer mentoring I } \\
\text { am more } \\
\text { committed to } \\
\text { completing my } \\
\text { course }\end{array}$ & 15.7 & 22.0 & 30.7 & 18.2 & 37.3 & 43.2 & 12.7 & 14.4 & 3.6 & 2.3 \\
\hline
\end{tabular}


One particular aspect of peer mentoring is reflected in students' perceptions of the role played by peer mentoring in addressing their individual needs. Table 4 shows that whilst both mentors and mentees found working with another student useful, it was the peer mentors who benefited the most overall. 
Table 4: Relationships \& Student Peer mentoring: The Wider Value of Participation: Mentees [M1] and Mentors [M2]

\begin{tabular}{|l|l|l|l|l|l|l|l|l|l|l|}
\hline $\begin{array}{l}\text { The value of } \\
\text { Peer mentoring } \\
\text { agree \% }\end{array}$ & \multicolumn{2}{l}{$\begin{array}{l}\text { Strongly } \\
\text { agree \% }\end{array}$} & \multicolumn{2}{l}{ Neutral \% } & \multicolumn{2}{l}{$\begin{array}{l}\text { Disagree } \\
\%\end{array}$} & \multicolumn{2}{l}{$\begin{array}{l}\text { Strongly } \\
\text { disagree } \\
\text { \% }\end{array}$} \\
\cline { 2 - 11 } & $\mathrm{M} 1$ & $\mathrm{M} 2$ & $\mathrm{M} 1$ & $\mathrm{M} 2$ & $\mathrm{M} 1$ & $\mathrm{M} 2$ & $\mathrm{M} 1$ & $\mathrm{M} 2$ & $\mathrm{M} 1$ & $\mathrm{M} 2$ \\
\hline $\begin{array}{l}\text { Peer mentoring } \\
\text { is responsive to } \\
\text { my individual } \\
\text { needs }\end{array}$ & 11.5 & 15.5 & 39.4 & 31.8 & 32.7 & 46.5 & 10.9 & 5.4 & 5.5 & .8 \\
\hline $\begin{array}{l}\text { Working with } \\
\text { another student } \\
\text { has been useful }\end{array}$ & 14.0 & 21.5 & 47.0 & 54.6 & 28.7 & 20.8 & 4.9 & 3.1 & 5.5 & .0 \\
\hline $\begin{array}{l}\text { I enjoy working } \\
\text { on a one-to-one } \\
\text { basis with a } \\
\text { student }\end{array}$ & 14.5 & 26.2 & 44.2 & 57.7 & 33.9 & 15.4 & 3.6 & .8 & 3.6 & .0 \\
\hline $\begin{array}{l}\text { I feel I can talk to } \\
\text { my mentor / } \\
\text { mentee if I am } \\
\text { worried }\end{array}$ & 15.7 & 13.9 & 39.2 & 36.1 & 27.1 & 41.0 & 9.6 & 8.2 & 8.4 & .8 \\
\hline $\begin{array}{l}\text { I feel } \\
\text { comfortable } \\
\text { working with my } \\
\text { mentor / mentee }\end{array}$ & 16.0 & 26.9 & 38.7 & 57.7 & 33.7 & 14.6 & 6.1 & .8 & 5.5 & .0 \\
\hline $\begin{array}{l}\text { I can talk to my } \\
\text { mentor / mentee } \\
\text { about things I } \\
\text { would not } \\
\text { discuss with a } \\
\text { member of staff }\end{array}$ & 15.8 & 13.0 & 35.2 & 39.8 & 29.1 & 35.8 & 9.7 & 9.8 & 10.3 & 1.6 \\
\hline
\end{tabular}

Given the pastoral nature of the peer mentoring programmes included within the study, the high percentage of respondents indicating that working with another student was 'useful' or 'very useful' gives some indication of the nature of the mentoring relationship between the students. Furthermore, that over half of all the respondents indicated that they could talk to their mentoring partner about things they would not discuss with a member of staff gives some indication of the value of peer support in higher education. That such support is available on a formal basis, from fellow students, can only add value to the university experience.

\section{Discussion}

In bringing the findings of the survey together, it quickly became evident that the key value of participation in peer mentoring in higher education is 
that the student experience is enhanced through promoting a sense of belonging. This finding, which supports the conclusions drawn from the wider 'What Works' Programme, supports the contention that 'belonging' is a central determinant of student success - both from an academic and social perspective (Thomas, 2012). Moreover, with regards to the student experience, peer mentoring represents the means by which HEIs can ease students' transition into higher education and in doing so begin to address issues of transition and retention.

For the recipients of peer mentoring-the mentees-the benefits of participating in peer mentoring programmes focus primarily on the move from school or college to university. This finding supports earlier work pointing to the importance of networking and student support (see for example, Morosanu et. al, 2010; Watson et. al, 2004). Moreover, the value of peer mentoring, in that it affords new students the means by which they are able to develop relationships with senior students early-on in their university life, should not be under-estimated. Additionally, whist the benefits of formal peer tutoring are explored elsewhere in the literature, with particular note being made of the psycho-social and cognitive value of peer learning (see for example, Anderson \& Boud, 1996; Congos \& Schoeps, 1998; Topping \& Ehly, 2001), the findings of this study are distinctive in that they suggest that despite being primarily focused on more social and pastoral issues, peer mentoring has in itself significant pedagogic value for both peer mentees and mentors, with benefits ranging from improved subject knowledge to increased confidence towards study. In summary, taking both social and pedagogic factors together, the role played by peer mentoring in assisting new students through the vital 'transition' phase of university life into their first year represents a valuable and fully sustainable management tool; a tool that HEIs need to fully utilise.

\section{Conclusion}

As the higher education sector enters a period of unprecedented uncertainty, the need to develop good practice and understanding becomes ever more important. For students, regardless of demographic or educational background, the decision to attend university represents a significant lifestep. Yet the UK student body is by its very nature heterogeneous. No individual student has exactly the same educational background, ambitions, experiences, needs or expectations as any other. There can be little argument that for the majority of students the move to university is a time of uncertainty, in which excitement and apprehension are experienced simultaneously. With student demands and expectations rising to reflect a shift towards consumerism as fees increase sharply, the need to provide a positive student experience must be given the highest priority. Bearing this in mind, two of the paper authors have developed a transferable model of peer mentoring that is available for use by any HEI wishing to introduce 
peer mentoring programme. Known as the Transition+ Model of Peer Mentoring, this tool represents a useful and useable outcome from 'What Works’ Programme (Andrews \& Clark, 2012).

In conclusion, throughout the course of this study, the one thing that has become increasingly evident is that a university's most valuable asset is its 'student-body'. By introducing peer mentoring, HEIs have the opportunity to make the most of this asset and in doing so create a true 'win-win-win' situation in which new students gain a sense of belonging, existing students develop new skills and universities experience reduced student attrition. Indeed, through engendering a sense of belonging, peer mentoring provides the ideal means by which established students are able to help new students succeed within what, for most, is a strange, new and uncertain world of higher education.

\section{Acknowledgements}

The paper authors wish to thank the funders of the What Works Programme (Paul Hamlyn Foundation and the Higher Education Funding Council for England).

\section{References}

Anderson, G., and Boud, D. (1996). Extending the role of peer learning in university courses, Research and Development in Higher Education, 19:1519.

Andrews, J. Clark, R. and Ingelby M. (2009) 'Pathways to Success Through Peer mentoring: A Mapping of the UK Higher Education Sector'. Aston University http://www1.aston.ac.uk/eas/research/groups/eerg/ (Accessed 27 September 2012)

Andrews, J. and Clark, R. (2012).' Peer Mentoring Works!' Institutional Manual. Available from: http://www.heacademy.ac.uk/assets/documents/what-worksstudent-retention/Aston_Peer_Mentoring_Institutional_Manual.pdf (Accessed 3October 2012)

Attwood, C., Singh, G., Prime, D., and Creasey, R. (2003). 2001 Home Office Citizenship Survey: People, Families and Communities. Research Study 270, London. Home Office.

Axon, K. (2012). 'Student Mentoring: Students Supporting Students', in Andrews, J., Clark R., \& Thomas, L. (eds) Compendium of Effective Practice in Higher Education Retention \& Success. pp 80 -102. Birmingham: Aston University \& Higher Education Academy.

Blackwell, J.E. (1989) 'Mentoring: An action strategy for increasing minority faculty', Academe, 75: 8-14.

Capstick, S., and Fleming, H., (2002). 'Peer Assisted Learning in an Undergraduate Hospitality Course: Second Year Students Supporting First Year Students in 
Group Learning', Journal of Hospitality, Sport and Tourism Education, 1. 1:69-75.

Chandler, D.E. and Kram, K.E. (2005) 'Mentoring and Development Networks in the New Career Context', in Gunz, H., \& Peiperl, M. (eds). Handbook of Career Studies, London: Sage.

Clark, R. and Andrews, J. (2012) 'Peer Mentoring in Higher Education: A Reciprocal Route to Success', in Andrews, J., Clark R., \& Thomas, L. (eds) Compendium of Effective Practice in Higher Education Retention \& Success, pp.71 - 75, Birmingham: Aston University \& Higher Education Academy.

Congos, D. H., and Schoeps, N., (1993). Does Supplemental Instruction really work and what is it anyway?', Studies in Higher Education, 18,2:165-176.

Congos, D.H.,and Schoeps, N., (1998). 'Inside Supplemental Instruction Sessions: One Model of What Happens that Improves Grades and Retention', Research and Teaching in Developmental Education, 15,1:12-20.

Cropper, C., (2000). 'Mentoring as an Inclusive Device for the Excluded: Black Students' Experiences of a Mentoring Scheme’, Social Work Education, 19, 6:697-607.

D’Abate, C.P., Eddy, E.R., and Tannenbaum, S.I. (2003) 'What's in a Name? A Literature-Based Approach to Understanding Mentoring, Coaching, and Other Constructs That Describe Developmental Interactions', Human Resource Development Review, 2: 360-384.

Davis Smith, J., Ellis, A., and Howlett, S., (2002). UK-Wide Evaluation of the Millennium Volunteers Programme, London: Department for Education and Skills Research Report 357, Department for Education and Skills.

Department for Communities and Local Government (DCLG) (2009). 2007-08 Citizenship Survey: Empowered Communities Topic Report. London. Department for Communities and Local Government. Available from: http://www.communities.gov.uk/documents/statistics/pdf/1345295.pdf (Accessed 19 May 2010)

Eby, L.T., Allen, T.D., Evans, S.C., Ng, T., and DuBois, L., (2008) 'Does Mentoring Matter? A Multi-disciplinary meta-analysis comparing mentored and non-mentored individuals', Journal of Vocational Behavior, 72, 2:254267.

Egerton, M., (2002). Higher Education \& Civic Engagement, British Journal of Sociology, 53, 4:603-620.

Enhrich, L.C., Hansford, B.,and Tennent, L., (2004). ,Formal Mentoring Programs in Education and Other Professions': A Review of the Literature, Educational Administration Quarterly, 40, 4:518-540.

Fox, A., \& Stevenson, L (2006). 'Exploring the Effectiveness of Peer mentoring of Accounting and Finance Students in Higher Education', Accounting Education: an international journal, 15, 2: 189-202.

Gaskin, J (1998). What Young People Want from Volunteering, London. Institute for Volunteering Research. 
Hartman, H.J (1990). 'Factors Affecting the Tutoring Process', Journal of Educational Development, 14, 2:2-6.

Hill, M., Russell, J.,and Brewis, G., (2009). Young People, Volunteering and Youth Projects: A Rapid Review of Recent Evidence, Available from: http://vinspired.com/uploads/admin_assets/datas/282/original/v_formative_ev aluation_rapid_evidence_review_Dec_2009_x_2.pdf (Accessed 19 July 2012)

Jacobi, M. (1991) 'Mentoring and Undergraduate Academic Success: A Literature Review', Review of Educational Research, 61, 4: 503-532.

Kram, K.E. (1983) 'Phases of the mentor relationship', Academy of Management Journal, 26, 4: 608-625.

Kreber, C. (2006) 'Introduction: The Possibility in Interpreting and Promoting Research’ Based Teaching. In Kreber, C. (ed), Exploring Research-Based Teaching: Edited Volume: New Directions for Teaching and Learning, San Francisco: Jossey Bass. 107,. 7-12

Levinson, D.J., Darrow, C.N., Klein, E.B., Levinson, M.H. and McKeen, B. (1978) The Seasons of a Man's Life, New York: Knopf.

Levinson, D., and Levinson, J. (1996). Seasons of a Woman's Life, New York. Knopf.

Moore, K.M. and Amey, M.J. (1988) 'Some Faculty Leaders are Born Women', in Sagaria, M.A.D., (ed), Empowering women: Leadership development strategies on campus. New directions for adult services, San Francisco: Jossey Bass.

Morosanu, L., Handley, K., and O'Donovan, B., (2010). 'Seeking support: researching first-year students' experiences of coping with academic life. Higher Education Research \& Development. 29, 6: 665-678.

Paton, G. (2011) 'Universities to Charge Average £8,600 Tuition Fees’, The Telegraph, 28 March, [Online] Available at http://www.telegraph.co.uk/education/universityeducation/8411357/Universiti es-to-charge-average-8600-tuition-fees.html (Accessed 27 September 2012).

Peyton, A.L., Morton, M., Perkins, M. and Dougherty, L.M. (2001). 'Mentoring in Gerontology Education: New Graduate Student Perspectives', Educational Gerontology, 27: 347-359.

Ragins, B.R., and Scandura, T.A., (1994). 'Gender differences in expected outcomes of mentoring relationships', Academy of Management Journal, 37, 2:957-971.

Reid, C.T., Topping, K.J., and McCrae, J., (1997). 'Reciprocal Peer Tutoring in Undergraduate Law Studies', Mentoring \& Tutoring: Partnership in Learning. 4. 3:3-10.Russell, I., (2005). A National Framework for Youth Action and Engagement: Report of the Russell Commission, London: The Russell Commission. Available from: http://vinspired.com/uploads/admin assets/datas/146/original/Russell_Commi ssion_summary.pdf (Accessed 19 July 2012) 
Sanchez, R.J., Bauer, T.N., and Paronto, M.E., (2006). 'Peer-Mentoring Freshmen: Implications for Satisfaction, Commitment, and Retention to Graduation', Academy of Management Learning \& Education, 5, 1:25-37.

Teichler, U. (2003) 'The Future of Higher Education and the Future of Higher Education Research', Tertiary Education and Management, 9, 3:171-185.

Thomas, L, (2012). Education at a Time of Change: A Summary of Findings and Recommendations from the What Works Programme. Action on Access, HEA, \& Paul Hamlyn Foundation. London. [Online] Available at http://www.heacademy.ac.uk/assets/documents/what-works-studentretention/What Works Summary Report.pdf (Accessed 19 July 2012)

Topping, K.J., (1996). 'The Effectiveness of Peer Tutoring in Further and Higher Education: A Typology and Review of the Literature', Higher Education, 32:321-345.

Topping, K.J., (2005). Trends in Peer Learning, Educational Psychology, 25, 6:631-645.

Topping, K.J., and Ehly, S.W., (2001).'Peer Assisted Learning: A Framework for Consultation', Journal of Educational and Psychological Consultation, 12, 2:113-132.

Trotter, E. and Roberts, C.A., (2006). 'Enhancing the Early Student Experience'. Higher Education Research \& Development. 25, 4:371-386.

Vernon, A., and Foster, L., (2002). 'Nonprofit Agency Perspectives of Higher Education Service Learning and Volunteerism', Journal of Nonprofit \& Public Sector Marketing, 10, 2: 207. Please check

vinspired, (2010) About us, [Online] Available at http://vinspired.com/aboutus/about-us (Accessed 21 July 2012).

Watson, G., Johnson, G.C., \& Austin, H. (2004) 'Exploring Relatedness to Field of Study as an Indicator of Student Retention', Higher Education Research \& Development, 23, 1: $57-72$ 